\title{
COVID-19 tents: specialized triage service, a temporal analysis of the patients' profile
}

\author{
Tenda COVID-19: serviço de triagem especializado, uma análise temporal do perfil de pacientes atendidos \\ Tienda COVID-19: servicio de triaje especializado, un análisis temporal del perfil de pacientes atendidos
}

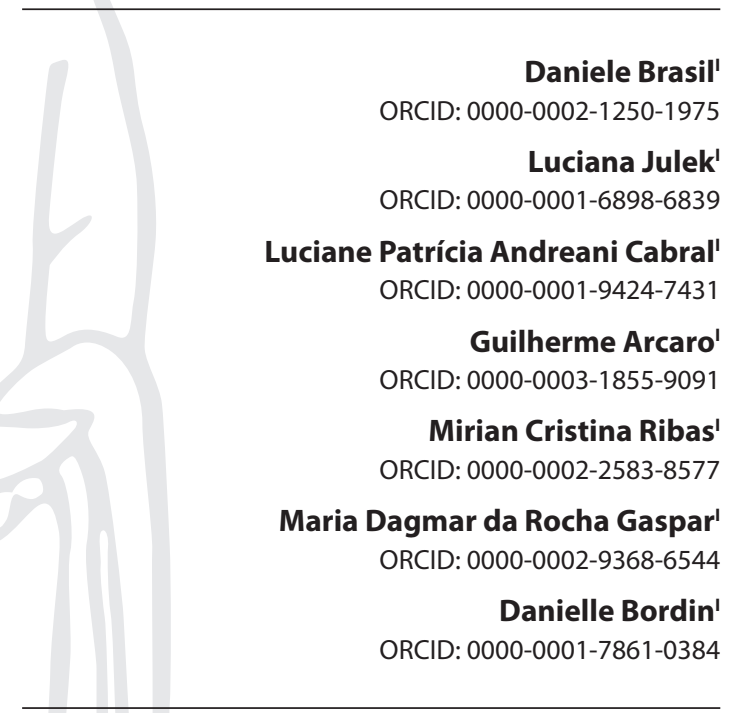

'Universidade Estadual de Ponta Grossa. Ponta Grossa, Paraná, Brazil.

How to cite this article: Brasil D, Julek L, Cabral LPA, Arcaro G, Ribas MC, Gaspar MDR, et al. COVID-19 tents: specialized triage service, a temporal analysis of the patients' profile.

Rev Bras Enferm. 2021;74(Suppl 1):e20200687. doi: http://dx.doi.org/10.1590/0034-7167-2020-0687

\section{Corresponding author:}

Danielle Bordin

E-mail: daniellebordin@hotmail.com

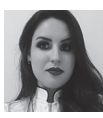

EDITOR IN CHIEF: Dulce Barbosa ASSOCIATE EDITOR: Hugo Fernandes

Submission: 06-30-2020

Approval: 10-03-2020

\section{ABSTRACT}

Objective: To analyze the change in the clinical-epidemiological profile of patients attended at the specialized triage service for COVID-19 (COVID-19 tent) in the first three months of operation. Methods: Cross-sectional study, with users attended from March 2020 to May $2020(n=379)$ at the COVID-19 tent in the city of Ponta Grossa, Paraná. Data collection was retrieved from an electronic form fed by tent professionals, which included sociodemographic characteristics, symptoms, risk factors of exposure, means of search and clinical conduct. Trend tests and chi-square tests were performed. Results: March showed a greater demand $(n=197)$, motivated by mild symptoms and direct search $(p<0.05)$. In the following months, there was a decrease in demand $(n=93 ; n=89)$, however the search for referrals, ambulances and conditions that required medical attention, observation and hospitalization increased $(p<0.05)$. The search resulting from exposure to risk factors has not changed ( $p>0.05)$ Conclusion: the profile has changed over time, reflecting, in the end, severe and critical symptoms, requiring intervention.

Descriptors: Health Profile; Triage; Admitting Department, Hospital; Secondary Care; Coronavirus Infections.

\section{RESUMO}

Objetivo: Analisar a mudança no perfil clínico-epidemiológico de pacientes atendidos no serviço de triagem especializado para COVID-19 (Tenda COVID-19) nos três primeiros meses de funcionamento. Métodos: Estudo transversal, com usuários atendidos de março a maio de 2020 ( $n=379$ ) na Tenda COVID-19 de Ponta Grossa, Paraná. Foram coletados dados de formulário eletrônico alimentado por profissionais da Tenda, contemplando características sociodemográficas, sintomatologia, fatores de risco de exposição, meio de busca e conduta clínica, e realizados teste de tendência e qui-quadrado. Resultados: Houve maior procura em março $(n=197)$, motivada por sintomatologia leve e busca direta $(p<0,05)$. Nos meses subsequentes, a procura diminuiu ( $n=93 ; n=89)$, mas aumentou a busca de forma referenciada, ambulância e quadros que requereram atendimento médico, observação e internação $(p<0,05)$. A busca decorrente de exposição a fatores de riscos não sofreu mudanças $(p>0,05)$. Conclusão: o perfil mudou ao longo do tempo, refletindo, ao final, quadros sintomatológicos graves e críticos, demandando intervenção.

Descritores: Perfil de Saúde; Triagem; Serviço Hospitalar de Admissão de Pacientes; Atenção Secundária à Saúde; Infecções por Coronavírus.

\section{RESUMEN}

Objetivo: Analizar el cambio del perfil clínico-epidemiológico de pacientes atendidos en el servicio de triaje especializado para COVID-19 (Tienda COVID-19) en sus primeros tres meses de funcionamiento. Métodos: Estudio transversal, con usuarios atendidos de marzo a mayo de 2020 ( $n=379$ ) en la Tienda COVID-19 de Ponta Grossa, Paraná. Datos recolectados de formulario electrónico completado por profesionales de la Tienda, contemplando características sociodemográficas, sintomatología, factores de riesgo de exposición, medio de búsqueda y conducta clínica. Se aplicaron tests de tendencia y Chi-cuadrado. Resultados: Hubo mayor concurrencia en marzo ( $n=197)$, con sintomatología leve y búsqueda directa $(p<0,05)$. En los meses siguientes se redujo la concurrencia $(n=93 ; n=89)$ aumentando igualmente la búsqueda referenciada, ambulancia y cuadros requiriendo atención médica, observación e internación $(p<0,05)$. La búsqueda derivada de exposición a factores de riesgo no cambió ( $p>0,05)$. Conclusión: El perfil cambió con el tiempo, reflejando finalmente cuadros sintomatológicos graves y críticos, demandando intervención.

Descriptores: Perfil de Salud; Triaje; Servicio de Admisión en Hospital; Atención Secundaria de Salud; Infecciones por Coronavirus. 


\section{INTRODUCTION}

The pandemic caused by the new coronavirus or SARS-CoV-2, which triggers the disease called COVID-19, has resulted in great social and economic shocks, becoming a global health disaster ${ }^{(1)}$.

The virus transmission is high and happens from an infected individual to a healthy one through respiratory droplets, mainly affecting the lungs ${ }^{(2)}$. There may be variation in symptoms with asymptomatic or mild symptoms that state a flu-like syndrome, and severe with respiratory failure and shock being the main complications $^{(3)}$.

Faced with this devastating setting, globally, health systems had to make changes in the organization of services and assistance. The Brazilian Ministry of Health created its care flows, according to its structure for providing services at different levels of care and patient's severity, in which serious and critical patients are the hospital's responsibility ${ }^{(4)}$.

Besides, the Ministry of Health issued recommendations to hospitals to organize a space outside the institution exclusively for the triage of patients with respiratory symptoms with or without fever and suspected or confirmed of COVID-19, for later hospitalization referral, if necessary ${ }^{(5)}$.

Given this assumption and to avoiding the collapse of the Sistema Único de Saúde (Unified Health System) in the region and ensuring greater patient safety and efficiency in care, the HU-UEPG (Regional University Hospital of Campos Gerais, of the State University of Ponta Grossa) set up the "Tenda COVID-19" (COVID-19 tent), an infrastructure outside the hospital facilities, specialized to hosting all suspected and confirmed patients from COVID-19, from a referral or directly, through a systematized service flow.

It is worth mentioning that even with wide advertising, social media and control of new more effective care flows, the population has doubts about the disease itself, the prevention measures, and other related contexts. Several factors lead the community to look for the service, such as showing clinical signs or even fear and anxiety, which, added to the doubts about the new service flows, cause the search for the service, often without the necessary indication.

Thus, it is important to invest in studies to measure the behavior and profile of individuals exposed and affected by the disease, so that more assertive strategies can be triggered in coping with COVID-19, as well as knowing the strategies in evidence, recalling the one listed in the present study.

\section{OBJECTIVE}

To analyze the change in the clinical-epidemiological profile of users attended at the specialized triage service for COVID-19 (COVID-19 tent) in the municipality of Ponta Grossa, in the state of Paraná during the first three months of its operation.

\section{METHODS}

\section{Ethical aspects}

The research was approved by the Research Ethics Committee with human beings of a Higher Education Institution, respecting the elements of Resolution 466/12 of the National Health Council and the Helsinki Declaration.

\section{Design, period, and study location}

This is a cross-sectional observational study guided by the STROBE tool, carried out from March 2020 to May 2020, at the specialized reference service for COVID-19 attendance, the COVID-19 tent, located in the municipality of Ponta Grossa, in the state of Parana, Brazil.

At the beginning of the COVID-19 Pandemic, the HU-UEPG set up a coping committee against COVID-19, composed of directors, managers, area coordinators, specialists in the various areas of knowledge and the Núcleo de Controle de Infecção Hospitalar (Hospital Infection Control Center) (NUCIH) team, which stimulated all strategies, protocols and care flows for suspected or confirmed patients with the disease.

Among the strategies, it is emphasized the employment of COVID-19 tent, an institution's external structure, built with the support of the Brazilian army, which works 24 hours a day, with space for admission, consultations, collection of laboratory exam and eight observation beds. It has a trained care team made up of 02 nurses and 01 doctor in each 24-hour shift. Also, there is a team of nurse technicians and nurses called "Posso ajudar" (I can Help), allocated at the institution's entrance doors to check the temperature, survey the presence of flu-like symptoms and handle suspicious cases to the tent.

The service is a referral for serving 12 municipalities belonging to the third regional health department in the state of Paraná. The offered service, besides to running as an open door (direct search), works together with regulation (referral search), where patients can be referred from Unidades Básicas de Saúde (UBS) (Basic Health Units), emergency care units and small hospitals in the region, following the ordered flow by the organization of the Rede de Atenção à Saúde (Health Care Network) of the regional health department in question.

At the COVID-19 tent, patients go through triage, following the recommended protocols by the Brazilian Ministry of Health ${ }^{(5)}$, and according to the patient's clinical condition, only patients who require hospitalization are admitted at the hospital, to avoid interferences in the institution's usual flow and to prevent possible risks of contamination. Patients with mild symptoms, are guided to home care and are monitored by a telephone service such as Telessaúde ("dial health") for 14 days $^{(4)}$.

All patients attended in the tent have their information recorded in an electronic form of the HU-UEPG, created especially to feed information inherent to the assistance, which is available to the Telessaúde ("dial health") team so that they can monitor the individuals.

It is worth noting that nursing plays an essential role in the innovation and management of strategies to control the dissemination of the new coronavirus in the institution, acting as a protagonist of the process, from logistics management, to the front line to assess complaints and assist in decision making for patient care, including the care guidelines for social isolation and in the execution of the call center. 


\section{Population or sample; inclusion, and exclusion criteria}

The study population was considered as the totality of individuals attended at the COVID-19 tent, from the first day of the service operation (March $16^{\text {th }}$ ) until May 31 $1^{\text {st }}, 2020(n=688)$.

It was considered as an inclusion criterion, being attended at the COVID-19 tent, and have its information recorded in the electronic form for the service's monitoring. As an exclusion criterion, employees of the institution were considered since the majority looked for the service at the request of $\mathrm{NUCIH}$ to perform a COVID-19 diagnostic examination $(n=309)$. Resulting in a final sample of 379 eligible individuals.

\section{Study protocol}

The data collection took place using the electronic form of the HU-UEPG, created especially to feed information inherent to the care of suspected and confirmed COVID-19 patients who went to the tent, based on the recommendations of the Ministry of Health ${ }^{(5)}$. The form is observed during the service in the tent, and the questions are asked to the patient or companion, when the patient can't answer. Along with patient identification, telephone and address, date and time that came in the service, sociodemographic characteristics, lifestyle, history of chronic diseases, history of recent trips to regions with a large number of cases, previous contact with a suspected or confirmed positive case of COVID, search for specialized service, search for other health services, presence of signs and symptoms of COVID-19, description of vital signs measured by nursing, description of nursing and medical care and clinical conduct of care carried out by the team.

As they are electronically collected data, the sociodemographic characteristics were absent mainly in March, the beginning of activities, and were fed more systematically in the subsequent months.

\section{Data analysis and statistics}

Data were tabulated using Microsoft Excel $2013^{\circledR}$ software and analysis performed using Statistical Package for the Social Sciences 18- SPSS $^{\circledR}$.

Linear and polynomial trend analysis was initially performed with $\mathrm{R}$-square values $\left(\mathrm{R}^{2}\right)$ along with the daily data of the quantity of assistance, to evaluate the trend of its distribution over time, which were presented in a graphical form. It is considered that the closer or equal to 1 the $\mathrm{R}^{2}$ value is, the more reliable the trend line is.

Then, the data were categorized and descriptively analyzed using absolute and relative frequency, and by the chi-square test at the $5 \%$ significance level. It was considered as a dependent variable the month in which the individual looked for the service (March, April, and May). It was decided to do it for the month and not for the 30-day setting since the variation of government strategies and people's behavior was more intense in March, at the beginning of the pandemic. As independent variables, it was considered the travel history and access to other health services, type of search, contact with COVID suspects, signs and symptoms of COVID-19 and clinical conduct of care developed.

\section{RESULTS}

The final sample of the study was made up of 379 individuals. It was found that the first month was the one with the highest number of individuals through triage, with a $50 \%$ decline in the following months. As seen in figure 1, in the analysis of linear trend there is a decline in attendance over time, however with great distance from the line data $\left(R^{2}=0.312\right)$. Demonstrating that the behavior of the search for health services presents a more polynomial trend $\left(\mathrm{R}^{2}=0.507\right)$, that is, more variant and fluctuating, with declines and additions.

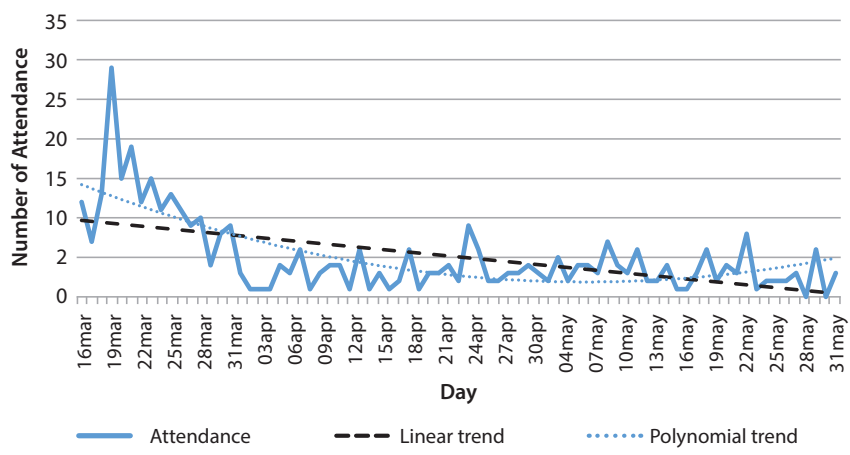

Figure 1 - Time series analysis of assistance made at COVID-19 tent, from March 2020 to May 2020

The profile of those assisted was mostly female, adult, married or in a domestic partnership, white, income of up to 02 minimum wages and resident in the municipality of the institution, nonsmokers and with one or more chronic diseases (Table 1).

Concerning the exposure risk factors for COVID-19, it was found that the massive majority who looked for the service did not leave the country or to the most endemic regions of the disease, also had no contact with a suspected or confirmed COVID- 19, with no significant difference concerning the months evaluated ( $p>$ 0.05) (Table 2).

When it comes to the motivating symptoms of the search for the service, it was found that the search was significantly increased in the second month and third month of the service by people with fever symptoms compared to the first month of the service installation $(p=0.03)$. Concerning the number of symptoms and respiratory symptoms, cough, nasal flaring, sore throat, sputum, nasal congestion, conjunctival congestion, coryza, an inverse relationship was found. Individuals with these symptoms showed greater demand in the first month, with a significant decrease in the subsequent months $(p<0.05)$ (Table 2$)$.

In general, it was observed that the time of greatest flow of care for the population is in the afternoon, the main arriving form is self-transport and the main clinical conduct of the team is guidance with hospital discharge (Table 3). It is worth mentioning that few were the individuals who needed to undergo a medical evaluation, to be under observation and hospitalized. However, as the months went on, these services' demands increased. Access by ambulance, demand for medical attention and clinical procedures such as observation for hours and hospitalization increased significantly in the second and third months after the service set up when compared to the first month $(p<0.001)$. (Table 3$)$. 
Table 1 - Sociodemographic and health profile of patients treated at the specialized service of COVID-19 tent, according to the month of service, Ponta Grossa, Paraná, 2020, (N = 379)

\begin{tabular}{|c|c|c|c|c|}
\hline & $\begin{array}{c}\text { March } \\
\text { n (\%) }\end{array}$ & $\begin{array}{l}\text { April } \\
\text { n(\%) }\end{array}$ & $\begin{array}{l}\text { May } \\
\text { n(\%) }\end{array}$ & $\begin{array}{l}\text { Total } \\
\text { n(\%) }\end{array}$ \\
\hline Quantity of assistance & $197(52.0)$ & $93(24.5)$ & $89(23.5)$ & $379(100)$ \\
\hline \multicolumn{5}{|l|}{ Sex } \\
\hline Male & $87(44.2)$ & $44(47.3)$ & $32(36.0)$ & $163(43.0)$ \\
\hline Female & $110(55.8)$ & $49(52.7)$ & $57(64.0)$ & $216(57.0)$ \\
\hline \multicolumn{5}{|l|}{ Age } \\
\hline Up to 59 years old & $173(87.8)$ & 77(82.7) & $66(74.2)$ & $316(83.3)$ \\
\hline 60 years or older & $24(12.2)$ & $16(17.3)$ & $23(25.8)$ & $63(16.7)$ \\
\hline \multicolumn{5}{|l|}{ Marital status } \\
\hline Married/domestic partnership & $28(14.2)$ & $54(58.1)$ & $41(46.1)$ & $123(32.5)$ \\
\hline Single & $10(5.1)$ & $22(23.7)$ & $27(30.3)$ & $59(15.6)$ \\
\hline Others & $5(2.5)$ & $11(11.8)$ & $20(22.5)$ & $36(9.5)$ \\
\hline Not informed & $154(78.2)$ & $6(6.5)$ & $1(1.1)$ & $161(42.5)$ \\
\hline \multicolumn{5}{|l|}{ Education } \\
\hline Illiterate & $0(0.0)$ & $2(2.2)$ & $16(18)$ & $18(4.7)$ \\
\hline Incomplete Elementary School & $4(2.0)$ & $18(19.4)$ & $24(27.0)$ & $46(12.1)$ \\
\hline Complete Elementary School & $7(3.6)$ & $16(17.2)$ & $9(8.0)$ & $32(8.4)$ \\
\hline Complete High School & $18(9.1)$ & $35(37.6)$ & $31(34.8)$ & $84(22.2)$ \\
\hline Higher Education and/or graduate & $5(2.5)$ & $10(10.8)$ & $7(7.9)$ & $22(5.8)$ \\
\hline Not informed & $163(82.74)$ & $12(12.9)$ & $2(2.2)$ & $177(46.7)$ \\
\hline \multicolumn{5}{|l|}{ Color } \\
\hline White & $35(17.8)$ & $66(71)$ & 74(79.6) & 175(46.17) \\
\hline Others & $11(5.6)$ & $12(12.9)$ & 14(15.7) & $37(9.8)$ \\
\hline Not informed & $151(76.6)$ & $15(16.1)$ & 1(1.12) & 167(44.1) \\
\hline \multicolumn{5}{|l|}{ Family income } \\
\hline Up to 2 minimum wages & $4(0.3)$ & $38(40.8)$ & $42(47.2)$ & $84(22.2)$ \\
\hline More than 2 minimum wages & $3(0.2)$ & $26(28.0)$ & $27(30.3)$ & $56(14.7)$ \\
\hline Not informed & $190(96.5)$ & $29(31.2)$ & $20(22.5)$ & $239(63.1)$ \\
\hline \multicolumn{5}{|l|}{ Municipality } \\
\hline Same of the Institution & 179(90.9) & 83(89.2) & $77(85.5)$ & $338(89.2)$ \\
\hline Another municipality & 18(9.1) & $10(10.8)$ & $12(13.5)$ & $40(10.6)$ \\
\hline \multicolumn{5}{|l|}{ NCD's } \\
\hline None & $9(4.6)$ & $38(40.9)$ & $40(44.9)$ & $87(23.0)$ \\
\hline One & $6(3.1)$ & $20(21.5)$ & $27(30.4)$ & $53(14.0)$ \\
\hline Two or more & $5(2.5)$ & $20(21.5)$ & 21 (23.6) & $46(12.1)$ \\
\hline Not informed & $177(89.8)$ & $15(16.1)$ & $1(1.1)$ & $193(50.9)$ \\
\hline \multicolumn{5}{|l|}{ Smoking } \\
\hline No & $24(12.2)$ & $47(50.5)$ & $51(57.3)$ & $122(32.2)$ \\
\hline Yes & $3(1.5)$ & $24(25.8)$ & $23(25.9)$ & $50(13.2)$ \\
\hline Former-smoker & $0(0.0)$ & $12(12.9)$ & 14 (15.7) & $26(6.8)$ \\
\hline Not informed & $170(86.3)$ & $10(10.8)$ & $1(1.1)$ & $181(47.8)$ \\
\hline
\end{tabular}

Table 2 - Exposure, signs, and symptoms referred by those treated at the specialized service of the COVID-19 tent, according to the search method, Ponta Grossa, Paraná, 2020, (N=379)

\begin{tabular}{|c|c|c|c|c|c|}
\hline & $\begin{array}{c}\text { March } \\
\text { n (\%) }\end{array}$ & $\begin{array}{l}\text { April } \\
\text { n(\%) }\end{array}$ & $\begin{array}{l}\text { May } \\
\text { n(\%) }\end{array}$ & $\begin{array}{l}\text { Total } \\
\text { n(\%) }\end{array}$ & $p$ value \\
\hline \multicolumn{6}{|c|}{ Traveled abroad or to a high-risk zone } \\
\hline No & $166(84.3)$ & $82(88.2)$ & $77(86.5)$ & $325(85.8)$ & \multirow{2}{*}{0.655} \\
\hline Yes & $31(15.7)$ & $11(11.8)$ & $12(13.5)$ & $54(14.2)$ & \\
\hline \multicolumn{6}{|c|}{ Contact with suspected or confirmed } \\
\hline No & $181(91.9)$ & $86(92.5)$ & 77 (86.5) & $344(90.8)$ & \multirow[t]{2}{*}{0.282} \\
\hline Yes & $16(8.1)$ & $7(7.5)$ & $12(13.5)$ & $35(9.2)$ & \\
\hline \multicolumn{6}{|l|}{ Fever } \\
\hline No & $128(65.0)$ & $46(49.5)$ & $50(56.2)$ & $224(59.1)$ & \multirow[t]{2}{*}{0.033} \\
\hline Yes & $69(35.0)$ & $47(50.5)$ & $39(43.8)$ & 155 (40.9) & \\
\hline \multicolumn{6}{|c|}{ Respiratory symptoms } \\
\hline No & $37(18.8)$ & $28(30.1)$ & $39(43.8)$ & $104(27.4)$ & \multirow[t]{2}{*}{$p<0.001$} \\
\hline Yes & $160(81.2)$ & $65(69.9)$ & 49 (56.2) & $275(72.6)$ & \\
\hline \multicolumn{6}{|l|}{ Cough } \\
\hline No & $37(18.8)$ & $38(40.9)$ & $47(52.8)$ & $122(32.2)$ & \multirow[t]{2}{*}{$p<0.001$} \\
\hline Yes & $160(81.2)$ & $55(59.1)$ & $42(47.2)$ & $257(67.8)$ & \\
\hline \multicolumn{6}{|c|}{ Dyspnea } \\
\hline No & $127(64.5)$ & $49(52.7)$ & $59(66.3)$ & $235(62.0)$ & \multirow{2}{*}{0.099} \\
\hline Yes & $70(35.5)$ & $44(47.3)$ & $30(33.7)$ & $144(38.0)$ & \\
\hline
\end{tabular}




\begin{tabular}{|c|c|c|c|c|c|}
\hline & $\begin{array}{c}\text { March } \\
\text { n (\%) }\end{array}$ & $\begin{array}{l}\text { April } \\
\mathrm{n}(\%)\end{array}$ & $\begin{array}{l}\text { May } \\
\text { n(\%) }\end{array}$ & $\begin{array}{l}\text { Total } \\
\mathbf{n}(\%)\end{array}$ & $p$ value \\
\hline \multicolumn{6}{|l|}{ Nasal flaring } \\
\hline No & $180(91.4)$ & $89(95.7)$ & $89(100.0)$ & $358(94.5)$ & 0.011 \\
\hline Yes & $17(8.6)$ & $4(4.3)$ & $0(0.0)$ & $21(5.5)$ & \\
\hline \multicolumn{6}{|l|}{ Sore throat } \\
\hline No & $100(50.8)$ & $59(63.4)$ & $62(69.7)$ & $221(58.3)$ & 0.006 \\
\hline Yes & $97(49.2)$ & $34(36.6)$ & $27(30.3)$ & $158(41.7)$ & \\
\hline \multicolumn{6}{|l|}{ Sputum } \\
\hline No & $107(54.0$ & $67(72.0)$ & $66(74.2)$ & $240(63.3)$ & 0.001 \\
\hline Yes & $90(45.7)$ & $26(28.0)$ & $23(25.8)$ & $139(36.7)$ & \\
\hline \multicolumn{6}{|c|}{ Nasal congestion } \\
\hline No & $103(52.3)$ & $70(75.3)$ & $75(84.3)$ & $248(65.4)$ & $p<0.001$ \\
\hline Yes & 94 (47.7) & $23(24.7)$ & $14(15.7)$ & $131(34.6)$ & \\
\hline \multicolumn{6}{|c|}{ Conjunctival congestion } \\
\hline No & $162(82.2)$ & $80(86.0)$ & $85(95.5)$ & $327(86.3)$ & 0.010 \\
\hline Yes & $35(17.8)$ & $13(14.0)$ & $4(4.5)$ & $52(13.7)$ & \\
\hline \multicolumn{6}{|c|}{ Swallowing difficulty } \\
\hline No & $156(79.2)$ & $70(75.3)$ & $72(80.9)$ & $298(78.6)$ & 0.627 \\
\hline Yes & $41(20.8)$ & $23(24.7)$ & $17(19.1)$ & $81(21.4)$ & \\
\hline \multicolumn{6}{|l|}{ Coryza } \\
\hline No & $92(46.7)$ & $65(69.9)$ & $67(75.3)$ & $224(59.1)$ & $p<0.001$ \\
\hline Yes & $105(53.3)$ & $28(30.1)$ & $22(24.7)$ & $155(40.9)$ & \\
\hline \multicolumn{6}{|c|}{ Intercostal recession } \\
\hline No & $184(93.4)$ & $88(94.6)$ & $84(94.4)$ & $356(93.9)$ & 0.902 \\
\hline Yes & $13(6.6)$ & $5(5.4)$ & $5(5.6)$ & $23(6.1)$ & \\
\hline \multicolumn{6}{|c|}{ Number of symptoms } \\
\hline None & $5(2.5)$ & $7(7.5)$ & $12(13.5)$ & $24(6.3)$ & $p<0.001$ \\
\hline Up to three & $49(24.9)$ & $36(38.7)$ & $44(49.4)$ & $129(34)$ & \\
\hline From 4 to 6 & $100(50.8)$ & $36(38.7)$ & $24(27)$ & $160(42.2)$ & \\
\hline More than 6 & $43(21.8)$ & $14(15.1)$ & $9(10.1)$ & $66(17.4)$ & \\
\hline
\end{tabular}

Table 3 - Profile of access and clinical conduct for those assisted in the specialized service of COVID-19 tent, according to the month of service, Ponta Grossa, Paraná, 2020, (N=379)

\begin{tabular}{|c|c|c|c|c|c|}
\hline & $\begin{array}{c}\text { March } \\
\text { n (\%) }\end{array}$ & $\begin{array}{l}\text { April } \\
\mathrm{n}(\%)\end{array}$ & $\begin{array}{l}\text { May } \\
\text { n(\%) }\end{array}$ & $\begin{array}{l}\text { Total } \\
\mathbf{n}(\%)\end{array}$ & $p$ value \\
\hline \multicolumn{6}{|l|}{ Search time } \\
\hline $0: 00$ to $5: 59 \mathrm{am}$ & $3(1.5)$ & $5(5.4)$ & $4(4.5)$ & $12(3.2)$ & 0.371 \\
\hline $6: 00$ to $11: 59 \mathrm{am}$ & $64(32.5)$ & $21(22.6)$ & $23(25.8)$ & $108(28.5)$ & \\
\hline $12: 00 \mathrm{pm}$ to $05: 59 \mathrm{pm}$ & 78(39.6) & $40(43.0)$ & $38(42.7)$ & $156(41.2)$ & \\
\hline $06: 00 \mathrm{pm}$ to $11: 59 \mathrm{pm}$ & $52(26.4)$ & $27(29.0)$ & $24(27)$ & $103(27.2)$ & \\
\hline \multicolumn{6}{|l|}{ Arrival } \\
\hline Own transport & $156(79.2)$ & $59(63.4)$ & $46(51.7)$ & $261(68.8)$ & $p<0.001$ \\
\hline Ambulance & $11(5.6)$ & $25(26.9)$ & $29(32.6)$ & $65(17.2)$ & \\
\hline Others* & $30(15.2)$ & $9(9.7)$ & $14(15.7)$ & $53(14.0)$ & \\
\hline \multicolumn{6}{|l|}{ Medical evaluation } \\
\hline No & $146(74.1)$ & $51(54.8)$ & $26(29.2)$ & $223(58.9)$ & $p<0.001$ \\
\hline Yes & $38(19.3)$ & $41(44.1)$ & $25(28.1)$ & $104(27.4)$ & \\
\hline Not informed & $13(6.6)$ & $1(1.1)$ & $38(42.7)$ & $52(13.7)$ & \\
\hline \multicolumn{6}{|l|}{ Clinical conduct } \\
\hline Guidance and discharge & $177(89.8)$ & $67(72.0)$ & $61(68.5)$ & $305(80.5)$ & $p<0.001$ \\
\hline Observation for 4 hours & 16(7.1) & $12(12.9)$ & $10(11.2)$ & $36(9.5)$ & \\
\hline Hospitalization & $6(3.0)$ & $14(15.1)$ & $18(20.2)$ & $38(10.0)$ & \\
\hline
\end{tabular}

Note: *Application/Public Transport/Walking.

\section{DISCUSSION}

In Brazil, at the end of March, the first month of investigation of the present study and when the World Health Organization declared COVID-19 as a pandemic, there were 5,717 confirmed cases of the disease ${ }^{(6)}$. The State of Paraná, in turn, accounted for 179 cases and the $3^{\text {rd }}$ regional health department 04 cases $^{(7)}$. In the following two months, these numbers went up to 87,187 and 514,849 cases, respectively, in Brazil( ${ }^{(6)}$, to 1,407 and 4,687 in Paraná and to 19 and 92 in the $3^{\text {rd }}$ regional health department ${ }^{(7)}$.
However, in the present study it was found that the demand for care at the referral service to suspected or confirmed COVID-19 patients was greater in March, with the demand decreasing to half in the following months, a condition opposite to that expected by the exponential growth of the disease. Such a situation can be justified by the fear and anxiety generated by the new virus and by the lack of information about the correct flow of care.

Authors stated in their study that the fear of contagion with SARS-CoV-2 can magnify the harm of the disease itself, because individuals with fear tend to panic and not think clearly and 
rationally and even trigger psychosomatic conditions ${ }^{(8)}$. In some cases, the uncertainty about contagion, risk of death, especially increased in NCD individuals, most of the sample in the present study, or the possibility of infecting family and friends can increase states of mental and emotional suffering, a condition that tends to be exacerbated in quarantined individuals ${ }^{(9,10)}$. It is suggested that these uncertainties were the motivational trigger for the search for referral services, especially at the beginning of the pandemic, as a source of answers to their wishes.

Still, the spread of fake news, theories and magic cures over the internet and social media can also be an obstacle to health services $^{(11,12)}$. The social distance and the overload of information about the pandemic by the media provoked great commotion in the population ${ }^{(10,13)}$ and the referral service for COVID-19 may have been pursued to provide correct information about the disease. Also, because of being hosted in a hospital environment, it brings a greater sense of resolvability, due to the contribution of dense technologies and specialized human resources.

The overvaluation of specialized services and hospital services compared to primary health care (APS), along with the lack of knowledge of the health care networks structuring and the hierarchy principle, presents as a consolidated challenge in health systems, especially in the Sistema Único de Saúde (Unified Health System) (SUS) ${ }^{(14)}$ and that has different impacts on the effectiveness and resolvability of the entire system and economic and social costs ${ }^{(15,16)}$.

Thus, it is crucial to invest in strategies, for beyond the care organization flows and referrals in the network, in strategies that empower popular knowledge regarding the operation of this flow and its etiology, symptoms and disease prevention. Once an enlightened population will seek care correctly, they will make better use of these services, optimizing resources, and their rights will be fully supported ${ }^{(17)}$. It is worth mentioning the developments and guarantee of the effectiveness of this context, nurses, who, beyond the other health professionals, remain at the forefront with greater contact with the patient and have a well-established profession role in health education.

The State sponsored actions in this direction, which caused direct repercussions in the search for a more conscious way in the second and third month of the service employment, as observed in the results with the decrease in the search for mild symptoms and an increase in the referenced search, and clinical conduct such as observation for 4 hours and hospitalization.

It is worth emphasizing that right at the beginning of the Pandemic, the Brazilian government determined the patient's care flow according to symptoms ${ }^{(4)}$. Considering that upper respiratory tract symptoms, fever, without severity criteria should seek care in APS (3). Meanwhile, patients with worsening respiratory symptoms should be referred, preferably referring to hospital and non-hospital emergency services, such as the COVID-19 tent of the institution under study ${ }^{(5)}$.

Besides this context, the state government, in partnership with public universities, launched the call center considered an important tool for the management of cases of individuals with high levels of anxiety, including symptoms suggestive of mild or moderate severity of COVID-19, further to expanding access to qualified guidance by specialized professionals.
Therefore, it can be inferred that the most effective and conscious search after the first month of care is also related to the better connection of the health teams to this flow and support from the call center, and, therefore, greater service functioning and dissemination of network understanding among its users.

From this perspective, the strategy of the systematized patients care flow is promising and can be a tool with great capability to face this pandemic situation. New care models to keep health services operating and safer can be useful and Telessaúde areas are used in coping contingency plans in several countries ${ }^{(18)}$.

It is worth mentioning that regarding exposure risk factors for COVID-19, despite being relevant for contagion, they were not the factors that most inspired the individuals to seek the tent service. The search for care mostly was due to showing signs and symptoms related to the respiratory system and high body temperature.

Coronavirus causes respiratory infections with symptoms similar to the flu syndrome, the most common clinical manifestations being fever above $37.8^{\circ} \mathrm{C}$ of a sudden outbreak, followed by cough (with or without secretion) or sore throat, and also possible dyspnea, nasal congestion, fatigue, myalgia, headache, where gastrointestinal symptoms such as diarrhea and vomiting are $\operatorname{rarer}^{(3)}$.

Moreover, the symptoms observed in this study are similar to what is stated in the literature ${ }^{(19-21)}$. The prospective study with Chinese patients also indicated the presence of respiratory symptoms such as cough in $76 \%$ of cases, dyspnea in $55 \%$, sputum in $28 \%$ and fever in $98 \%{ }^{(19)}$. In a cohort study in Spain with individuals who were hospitalized, the presence of fever was found in $72 \%$ of patients, coughing in $67 \%$ and dyspnea in approximately $50 \%{ }^{(20)}$. Likewise, a descriptive study with New York patients showed that about 31\% had a fever and about $28 \%$ had a respiratory disorder requiring support with oxygen therapy during triage ${ }^{(21)}$.

Considering these frequent symptoms showed by the individuals who searched for the services, it resulted in clinical conduct, mostly guidance and discharge. Within this, an express recommendation was encouraged that individuals with the COVID-19 symptoms remain at home for 14 days in isolation, without hosting visits, following specific measures such as the restricted use of personal objects such as: silverware, use restriction of rooms and materials in the house, keeping a minimum distance of 2 meters from other residents, carrying out etiquette on health care, such as wearing a mask, hand hygiene, proper surface hygiene ${ }^{(3,22)}$.

Despite that the search profile has changed in the last two months, there is still a high number of individuals who search the service directly, with mild symptoms, without the need to undergo a medical evaluation and with the outcome of clinical guidance and discharge. Greater mobilization of the population is necessary for a conscious, assertive search to ensure that hospital services and referral services for suspected or confirmed COVID-19 patients can appropriately serve patients, without overcrowding and without the need to dismiss human resources and inadequate specialized materials, preventing the collapse of the health system.

Given that, it is worth highlighting the need of providing and disseminating even more health guidance and education structures and services, through Telessaúde and strengthening the flows and protocols in which APS is a protagonist in the 
management process of healthcare of suspected or confirmed COVID-19 patients, with early identification, risk stratification and correct referral of cases. Strategies like these ensure greater system efficiency and optimize the economic and social costs caused by the COVID-19 pandemic.

\section{Limitations of the Study}

The limitation of the study is the loss of sociodemographic data from the first month of investigation, thus not allowing to perform statistical analysis in this profile context. However, the purpose of the present study was to investigate changes in access to the service in terms of symptoms, exposure risk factors and the means of search, consequently not impacting the scope of the study.

It is worth mentioning that, as the exposure to SARS-CoV-2 presents itself in a very peculiar way in each region and that the circumstances have been changing quickly day by day, it is required to encourage more research aimed at investigations that explore the functioning of services, with clarification of profile in time series in different regions and health services.

\section{Contributions to the Area}

Regarding the searching profile of specialized care, here demonstrated, it is worth noting that the strategy of setting up a tent outside the hospital environment for clinical triage is promising, since it ensures the most appropriate organization for the patients flow. Only patients who have demands that require interventions of a higher level of complexity go into the hospital for service. A condition that enhances the guarantee of comprehensive, hierarchical, and regionalized care, basic principles of the Brazilian health system, with the nurse being the main protagonist in the accomplishment of this proposal.

Considering the above, the study brings an unprecedented contribution to the theme, and may serve as a subsidy to guide managers to outline increasingly assertive strategies in coping with the COVID-19 pandemic.

\section{CONCLUSION}

It is concluded that the demand for the referral service to suspected or confirmed patients was higher in the first set up month, motivated by a mild symptom condition, decreasing the demand in the following months, even with the expressive increase in the number of reported cases. However, the search in the months following the employment, were more aware and efficient, in a referenced way, concerning symptomatic conditions that require significantly more clinical procedures such as observation and hospitalization, consistent with the protocols of care flows employed to care for suspected or confirmed patients of COVID-19.

\section{REFERENCES}

1. Lim WS, Liang CK, Assantachai P, Auyeung TW, Kang L, Lee WJ, et al. COVID-19 and Older People in Asia: AWGS Calls to Actions. Geriatr Gerontol Int. 2020;20(6):547-58. doi: 10.1111 / ggi.13939

2. Harapan H, Itoh N, Yufika A, Winardi W, Keam S, Te H, et al. Coronavirus disease 2019 (COVID-19): A literature review. J Infect Public Health. 2020;13(5):667-73. doi: 10.1016/j.jiph.2020.03.019

3. Ministério da Saúde (BR). Coronavírus: COVID-19 [Internet]. 2020[cited 2020 Jun 30]. Available from: https://coronavirus.saude.gov.br/

4. Secretaria de Atenção Primária à Saúde. Protocolo de manejo clínico do coronavírus (covid-19) na atenção primária à saúde [Internet]. versão 9. Brasilia: Ministério da Saúde; 2020 [cited 2020 Jun 30]. 1-41 p. Available from: http://189.28.128.100/dab/docs/portaldab/ documentos/20200504_ProtocoloManejo_ver09.pdf

5. Agência Nacional de Vigilância Sanitária. Nota Técnica No 04/2020 GVIMS / GGTES/ANVISA. Orientações para Serviços de Saúde: Medidas de Prevenção e Controle que Devem Ser Adotadas Durante a Assistência aos Casos Suspeitos ou Confirmados de Infecção pelo novo coronavírus (2019- nCoV). [Internet]. Agência Nac Vigilância Sanitária - Anvisa. 2020 [cited 2020 Jun 30 ];1-92. Available from: http://portal.anvisa.gov.br/documents/33852/271858/Nota+T\%C3\%A9cnica+n+04-2020+GVIMS-GGTES-ANVISA/ ab598660-3de4-4f14-8e6f-b9341c196b28

6. World Health Organization. Director-General's opening remarks at the media briefing on COVID-19 [Internet]. 2020. Available from: https:// www.who.int/dg/speeches/detail/who-director-general-s-opening-remarks-at-the-media-briefing-on-covid-19---25-may-2020

7. Secretaria de Saúde do Estado do Paraná. Informe Epidemiológico: COVID-19 [Internet]. Curitiba: Secretária de Saúde; 2020 [cited 2020 Jun 30]. 17 p. Available from: http://www.saude.pr.gov.br/Pagina/Coronavirus-COVID-19

8. Ahorsu DK, Lin CY, Imani V, Saffari M, Griffiths MD, Pakpour AH. The Fear of COVID-19 Scale: development and initial validation. Int J Ment Health Addict. 2020. doi: 10.1007/s11469-020-00270-8

9. Shigemura J, Ursano RJ, Morganstein JC, Kurosawa M, Benedek DM. Public responses to the novel 2019 coronavirus (2019-nCoV) in Japan: Mental health consequences and target populations. Psychiatry Clin Neurosci. 2020;74(4):281-2. doi: 10.1111/pcn.12988

10. Faro A, Bahiano MA, Nakano TC, Reis C, Silva BFP, Vitti LS. COVID-19 e saúde mental: a emergência do cuidado. Estud Psicol. 2020;37:e200074. doi:10.1590/1982-0275202037e200074

11. Rathore F, Farooq F. Information Overload and Infodemic in the COVID-19 Pandemic. J Pak Med Assoc. 2020;70(5):S-162-65. doi:10.5455 / JPMA.38 
12. Wilder-Smith A, Freedman DO. Isolation, quarantine, social distancing and community containment: Pivotal role for old-style public health measures in the novel coronavirus (2019-nCoV) outbreak. J Travel Med. 2020;27(2):1-4. doi:10.1093/jtm/taaa020

13. Garcia Filho C, Vieira LJES, Silva RM. Internet searches for measures to address COVID-19 in Brazil: a description of searches in the first 100 days of 2020. Epidemiol Serv saude. 2020;29(3):e2020191. doi: 10.5123/s1679-49742020000300011

14. Pitilin EB, Lentsck MH. Primary Health Care from the perception of women living in a rural area. Rev Esc Enferm USP. 2015;49(5):725-31. doi: $10.1590 /$ S0080-623420150000500003

15. Tesser CD, Poli Neto P. Specialized outpatient care in the unified health system: how to fill a void. Cien Saude Coletiva. 2017;22(3):941-51 doi: 10.1590/1413-81232017223.18842016

16. Assis MMA, Nascimento MAA, Pereira MJB, Cerqueira EM. Comprehensive health care: dilemmas and challenges in nursing. Rev Bras Enferm. 2015;68(2):333-8. doi: 10.1590/0034-7167.2015680221i

17. Silva ACS, Soares IRB, Campos KFC, Castro MCS. Primary Care from the perspective of the users of the Unified Health System: a bibliographic review. Rev Sustinere [Internet]. 2019[cited 2020 Jun 30];7(1):46-72. Available from: https://go.gale.com/ps/anonymous?id=GALE\%7CA603 $411082 \&$ sid $=$ googleScholar $\& v=2.1 \& i t=r \&$ linkaccess $=$ abs\&issn $=23590424 \& p=A O N E \& s w=w$

18. Caetano R, Silva AB, Guedes ACCM, Paiva CCN, Ribeiro GR, Santos DL, et al. Challenges and opportunities for telehealth during the COVID-19 pandemic: ideas on spaces and initiatives in the Brazilian context. Rep Public Heal. 2020;36(5):e00088920. doi: 10.1590/0102-311x00088920

19. Huang C, Wang Y, Li X, Ren L, Zhao J, Hu Y, et al. Clinical features of patients infected with 2019 novel coronavirus in Wuhan, China. Lancet. 2020;395(10223):497-506. doi: 10.1016/S0140-6736(20)30183-5

20. Borobia AM, Carcas AJ, Arnalich F, Alvarez-Sala R, Montserrat J, Quintana M, et al. A cohort of patients with COVID-19 in a major teaching hospital in Europe. J Clin Med. 2020;9(6):1733-43. doi: 10.1101/2020.04.29.20080853

21. Richardson S, Hirsch JS, Narasimhan M, Crawford JM, McGinn T, Davidson KW, et al. Presenting Characteristics, Comorbidities, and Outcomes among 5700 Patients Hospitalized with COVID-19 in the New York City Area. JAMA - J Am Med Assoc. 2020;323(20):2052-9. doi: 10.1001/ jama.2020.6775

22. Oliveira AC, Lucas TC, Iquiapaza RA. What Has the Covid-19 Pandemic taught us about adopting preventive measures? Texto Contexto Enferm. 2020;29:e20200106. doi: 10.1590/1980-265x-tce-2020-0106 